\title{
Isolation and identification of bacterial protease enzyme of leather waste
}

\author{
A. Pertiwiningrum ${ }^{1}$, F. D. Anggraini ${ }^{1}$, N. A. Fitrianto ${ }^{1}$ and Rochijan ${ }^{2}$ \\ ${ }^{1}$ Department of Animal Product Technology, Faculty of Animal Science, \\ Universitas Gadjah Mada, Jl. Fauna 3 Bulaksumur, Yogyakarta 55281 - Indonesia \\ ${ }^{2}$ Department of Animal Production, Faculty of Animal Science, \\ Universitas Gadjah Mada, Jl. Fauna 3 Bulaksumur, Yogyakarta 55281 - Indonesia \\ Corresponding E-mail: artiwi@mail.ugm.ac.id
}

Received August 09, 2016; Accepted January 16, 2017

\begin{abstract}
ABSTRAK
Penelitian ini bertujuan untuk mengisolasi dan mengidentifikasi bakteri penghasil enzim protease dari limbah cair dan padat penyamakan kulit, dan mengetahui karakterisasi aktivitas enzim yang dihasilkan. Isolasi bakteri menggunakan sampel limbah cair dan padat dari limbah penyamakan kulit yang diambil dari 4 penampungan limbah yang berbeda (tiga limbah cair dan 1 limbah padat dari fase unhairing). Data hasil isolasi bakteri, pengukuran pertumbuhan bakteri pada OD $600 \mathrm{~nm}$, identifikasi bakteri dan pemekatan enzim $60 \%$ ammonium sulfat dianalisis secara deskriptif. Data uji diameter koloni, diameter zona bening, indeks proteolitik dan uji karakterisasi aktivitas enzim terhadap $\mathrm{pH}$ dan suhu yang berbeda-beda dianalisis dengan menggunakan analisis ragam, apabila terdapat perbedaan dilanjutkan dengan uji Duncan's New Multiple Range Test. Hasil isolasi bakteri sampel limbah cair dari kolam penampungan limbah yang kedua (L2) diuji lebih lanjut karena menunjukkan adanya aktivitas proteolitik. Identifikasi isolat bakteri L2 mempunyai morfologi koloni berbentuk bulat, berwarna putih, tepian rata dan elevasi cembung, morfologi sel berbentuk bacillus, warna merah, gram negatif, tidak motil, katalase positif, dan gelatin negatif. Aktivitas enzim tertinggi ditunjukkan pada $\mathrm{pH} 11$ dengan aktivitas unit enzim $45.18 \pm 1.77 \mathrm{U} / \mathrm{mL}$ dan aktivitas spesifik enzim $43.19 \pm 1.69 \mathrm{U} / \mathrm{mg}$ dan suhu $40^{\circ} \mathrm{C}$ dengan aktivitas unit enzim $54.02 \pm 1.89 \mathrm{U} / \mathrm{mL}$ dan aktivitas spesifik enzim $51.65 \pm 1.8 \mathrm{U} / \mathrm{mg}$. Aktivitas enzim dari protease yang terpresipitasi ammonium sulfat $60 \%$ menunjukkan hasil yang lebih tinggi (75.8 $\mathrm{U} / \mathrm{mL}$ ) daripada protease kasar.
\end{abstract}

Kata kunci : Isolasi bakteri, enzim protease, limbah penyamakan kulit, Unhairing

\begin{abstract}
The objectives of this study were to isolate and identify bacteria which produced protease enzyme from liquid and solid waste of tannery, and their characterization of enzymatic activities. The bacterial isolation used a sample of liquid and solid waste from leather waste which taken from a different waste reservoirs (three liquid waste and one solid waste in unhairing phase). Data of the isolated bacteria, OD $600 \mathrm{~nm}$ bacterial growth, the identification of bacteria, and enzyme precipitation with $60 \%$ ammonium sulfate were analyzed descriptively. The colony diameter, diameter of clear zone, proteolytic index, and enzymatic activities characterization on difference of $\mathrm{pH}$ and temperature were analyzed using Completely Randomized Design, followed by Duncan's New Multiple Range Test. The second sample from four samples of the isolated bacteria was tested further for their proteolytic activity. The morphology of the colony was circle, white, flat ledges and convex elevation, the basal cell morphology was red, gram-negative, non-motile, catalase positive and gelatin negative. The highest activity of
\end{abstract}


enzyme on $\mathrm{pH} 11$ with activity unit enzyme $45,18 \pm 1,77 \mathrm{U} / \mathrm{ml}$ and specific enzyme activity $43,19 \pm 1,69$ $\mathrm{U} / \mathrm{mg}$ and temperature of $40^{\circ} \mathrm{C}$ activity unit enzyme $54,02 \pm 1,89 \mathrm{U} / \mathrm{ml}$ and specific enzyme activity $51,65 \pm 1,8 \mathrm{U} / \mathrm{mg}$. The activity of enzyme from protease were precipitated ammonium sulfate $60 \%$ showed a higher result of $(75,8 \mathrm{U} / \mathrm{ml})$ rather than rough protease.

Keywords: Isolation of bacteria, protease enzyme, Tannery waste, Unhairing

\section{INTRODUCTION}

The most important process in the tannery is the removal of non-collagenous compounds, and the rate of this removal determines the quality of the leather (Widodo, 1984). The addition of enzymes is needed to simplify the process of leather tanning. In addition to facilitate the tanning process, the enzymes can also replace the chemicals, which means a reduction in the amount of chemical waste (Alexander et al., 1991). Therefore, the production of enzymes is needed for leather tanning process.

Protease enzyme can be produced from animals, plants and microorganism products. When the enzyme derived from plant and animal products are used, it may have drawbacks. This is because the plant tissues contain hazardous materials such as phenolic compounds. Protease enzymes used in the industry are generally produced from microorganisms. The use of microorganisms to produce the protease enzyme has several advantages. It can be easily produced on a large scale, it has relatively short production time, and it can be produced in a sustainable manner with a relatively low cost (Thomas, 1989).

Protease was one of the three groups of enzymes which was commercially traded with the value of $60 \%$ of the total sales of enzymes and applied as biological catalyst in food industry, detergent industry, and leather industry (Suhartono, 2000; Agrawal et al., 2004; Kumari 2014). The global market for industrial enzymes reached 3 to 4 billion dollars per year, 4 to 5 million of them were in Indonesian market which was fully imported from enzyme-producer countries (Rajasa, 2003).

Proteases played a major role in many biological functions, ranging from the level of cells, organs, to organisms, namely to carry out metabolic reactions and regulatory functions (Rao et al., 1998; Vázquez et al., 2008 ).

Several microorganisms that had been known as protease-producers in commercial applications were Bacillus, Lactobacillus, Pyrococcus, Termonospora rhizopus, Mucor,
Endothia and Aspergillus (Ward et al., 2009). The proteolytic enzymes made from bacteria were introduced in 1960s by Gebruder Schyder from Switzerland and Novo Industries $\mathrm{A} / \mathrm{S}$ from Denmark, and until today, the use of bacteria as protease-producer has a great opportunity. There are several types of bacteria Bacillus capable of producing protease (Kumari, 2014; Tejaswini et al., 2014). Several types of Bacillus were reportedly capable of producing protease, among others was B. thermoglucosidasius AF-01 (Fuad et al., 2004) and B. subtilis (Tejaswini et al., 2014).

The objectives of this study were to isolate and identify the bacteria producing protease enzyme from liquid and solid waste of tannery. The protease are characterized for enzymatic activities. Results of this study are proposed as alternate source of protease enzyme contributing to tanner industry, especially in unhairing phase.

\section{MATERIALS AND METHODS}

\section{Sample Collection Procedures}

Tannery wastewater samples were obtained from tanning industry and the samples of liquid and solid waste (Figure 1) were collected from four different reservoirs as as L1, L2, L3 and L4 (Figure 2). The L1 was isolated from liquid waste sample of first waste storage, L2 was isolated from liquid waste sample of second waste storage, L3 was isolated from liquid waste sample of third waste storage and L4 was isolated from solid waste sample (sludge). The types of waste used in this study were liquid and solid wastes. Samples of the waste were taken from three tannery waste storage ponds. The first pool contained tannery waste before processed, the second pool contained tannery waste which was processed by aeration, and the third pool contained tannery waste after being processed. The solid waste samples were taken from the solid waste container in the form of sludge.

\section{The Isolation of Bacteria}

Samples of liquid and solid waste were taken $1 \mathrm{~mL}$ each. The concentration was then reduced 


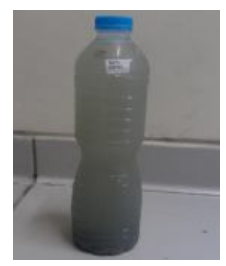

(a)

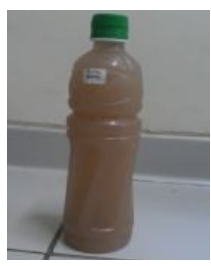

(b)

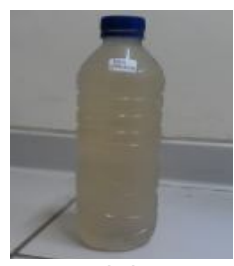

(c)

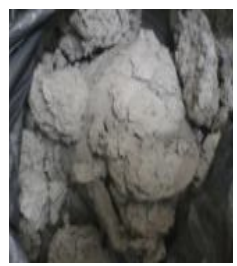

(d)

Figure 1. Tannery wastewater samples which obtained from tanning industry. The symbols (a) Liquid waste sample of first waste storage, (b) Liquid waste sample of second waste storage, (c) Liquid waste sample of third waste storage and (d) Solid waste sample (sludge).

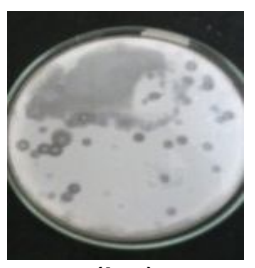

(L1)

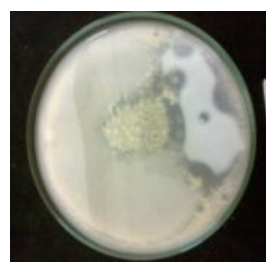

(L2)

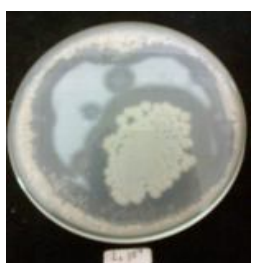

(L3)

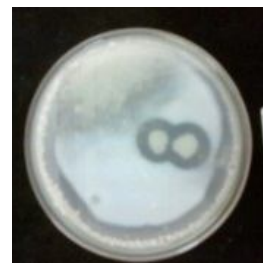

(L4)

Figure 2. Isolation results of tannery solid and wastewater samples were obtained from tanning industry. The symbols (L1) was isolate L1 from sample (a), (L2) was isolate L2 from sample (b), (L3) was isolate L3 from sample (c) and (L4) was isolate L4 from sample (d).

with a serial dilution from $10^{-1}$ to $10^{-10}$ using sterile distilled water. The dilution results of $10^{-8}$, $10^{-9}$ and $10^{-10}$ were each taken $100 \mu \mathrm{m}$, planted with pour plate method on skim media, and incubated at $27^{\circ} \mathrm{C}$ for 72 hours. The positive test was marked by a clear zone formed around the colonies. The single colony which produced the clear zone is then purified by replanting isolated bacteria in skim media and incubated at $27^{\circ} \mathrm{C}$ for 72 hours. The purification results were grown on agar slant skim media, incubated at $27^{\circ} \mathrm{C}$ for 72 hours, and stored at $5^{\circ} \mathrm{C}$ (Rahayu, 1991; Miyamoto et al., 2002 with modifications).

The purified bacterial isolates were then tested for their ability to grow in an alkaline medium with $\mathrm{pH}$ of $7,8,9,10,11$ and 12 . The addition of $\mathrm{NaOH}$ helped with the adjustment of the medium's $\mathrm{pH}$. The pre-culture that would be planted to the medium was diluted to $10-10^{-10}$ with sterile distilled water. Pre-culture $(0.1 \mathrm{~mL})$ was poured into the dense agar medium and flattened with dirgalski, incubated at $37^{\circ} \mathrm{C}$ for 24 hours, and observed to determine the growth of the colony at each $\mathrm{pH}$.

\section{Identification of Bacteria}

The identification of bacteria isolates included morphology test, gram staining, catalase test and motility test.

\section{Measurement of Colony Diameter and Diameter of Clear Zone}

One drop of pre-culture was planted in agar medium with different $\mathrm{pH}$ treatment of $7,8,9,10$, 11 and 12, then incubated for 72 hours. The diameter of bacterial colonies and the clear-zone diameter were measured with calipers (Schmidt $e t$ al., 2011).

\section{Measurement of Proteolytic Index}

Proteolytic activity of the bacteria grown in skim medium was indicated by the appearance of a clear-zone around the colony formed. Proteolytic index was defined by measuring the diameter of the clear zone and the diameter of bacterial colony. The proteolytic index is the ratio of clear area's diameter to the diameter of bacterial colonies (Baehaki et al., 2011).

\section{Protein Measurement in Protease Enzyme}

One $\mathrm{mL}$ Protease enzyme was added with 5 $\mathrm{mL}$ of reagent $\mathrm{C}$, shaken immediately and allowed to stand at room temperature for 10 minutes. This was then added with $0.5 \mathrm{~mL}$ of reagent $\mathrm{D}$, shaken 
immediately, and left at room temperature for 30 minutes. The absorbance was measured with a spectrophotometer at a wavelength of $750 \mathrm{~nm}$. The protein level was determined by comparing the absorbance with the obtained BSA standard curve (Noble and Bailey, 2009).

\section{Protease Activity Test}

The alkaline protease activity test included the blank measurement, standard measurement of tyrosine and sample measurement. Buffer solution $(0.5 \mathrm{~mL}$ ) having $\mathrm{pH} 7$ to 12 , plus $0.5 \mathrm{~mL}$ of casein and $1 \mathrm{~mL}$ of sterile distilled water (blank measurement), $1 \mathrm{~mL}$ of tyrosine (standard measurement), and $1 \mathrm{~mL}$ of the sample (sample measurement) was poured to each test tubes. They were incubated at $37^{\circ} \mathrm{C}$ for 10 minutes, then added with $1 \mathrm{~mL}$ of TCA $10 \%$, and incubated again for 10 minutes at room temperature, and filtered with Whatman filter paper no. 1. The filtrate was taken at $0.75 \mathrm{~mL}$, then added with 2.5 $\mathrm{mL}$ of $\mathrm{Na}_{2} \mathrm{CO}_{3}(0.5 \mathrm{M}), 0.5 \mathrm{~mL}$ of folin reagent, and allowed to stand for 15 minutes at room temperature. The absorbance was then read at 578 nm (Nadeem et al., 2007; Ahmed et al., 2008; with modifications) .

\section{Enzyme Precipitaion with Ammonium Sulfate}

Enzyme precipitation was done by using ammonium sulfate $(361 \mathrm{~g} / \mathrm{L})$. About 36.1 grams of ammonium sulfate was added to $100 \mathrm{~mL}$ of crude enzyme until dissolved in magnetic stirrer with the speed of 2 to 3 . After that, the solution was stored at $4^{\circ} \mathrm{C}$ for 12 to 24 hours, then $3300 \mathrm{~g}$ were centrifuged for 15 minutes. The supernatant was discarded and the pellet was taken as the precipitated enzyme. It was then added with $1 \mathrm{~mL}$ Phosphate Buffer Saline (PBS).

\section{Data Analysis}

The data from bacterial isolation, identification of bacteria and enzyme precipitaion using $60 \%$ ammonium sulfate were analyzed

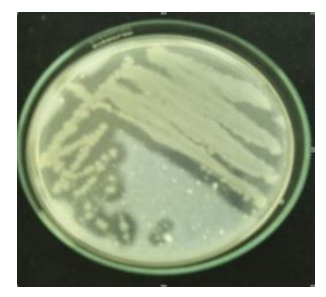

Figure 3. Purification result of bacterial isolate L2, from sample (b). descriptively and described with tables, pictures and graphs. The data of colony diameter, diameter of clear-zone, proteolytic index, and characterization of enzyme activity at different $\mathrm{pH}$ $(7,8,9,10,11$ and 12) and different temperatures $\left(40^{\circ} \mathrm{C}, 50^{\circ} \mathrm{C}, 60^{\circ} \mathrm{C}\right)$ were analyzed using analysis of variance based on completely randomized design. Duncan's new multiple range test (DMRT) was used when there was difference effect among treatments.

\section{RESULTS}

\section{Isolation of Bacteria}

Figure 2 shows bacteria isolate which was obtained from the tannery waste at PT. Adi Satria Abadi Yogyakarta (L1, L2, L3 and L4). A high proteolitic activity of the results of bacterial isolation was selected. This isolate with the high proteolitic activity was characterized by the appearance of a clear zone around the biggest colony of bacteria (isolate L2, Figure 3).

\section{Identification of Bacteria}

The identification of bacterial isolate L2 was based on the macroscopic morphology: spherical shape, elevation convex, flat ledges, and white colored colonies (Figure 4). The identification based on microscopic morphology were bacillus or rod colonies of cells, pink and gram-negative. Bacterial isolate L2 was non-motile and catalasepositive. Based on the identification, the bacteria in isolate L2 was predicted to belonged to the Bacillus group.

\section{Measurement of Colonies' Diameter and Clear- Zone Diameter}

The data analysis of diameter measurements of bacterial colony L2 in the media with different $\mathrm{pH}$ showed that the diameter of bacterial colonies grown in medium with $\mathrm{pH} 7$ was not significantly different from the ones with $\mathrm{pH} 8, \mathrm{pH} 9$ and $\mathrm{pH}$ 12 (Table 1). However, this was significantly different from the ones with $\mathrm{pH} 10$ and 11 . The

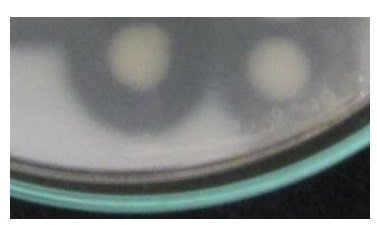

Figure 4. Morphology test of bacterial isolate L2's colony, from sample (b) 
media with different $\mathrm{pH}$ treatments showed significant difference in the size of the colonies' diameter after the treatment with $\mathrm{pH} 10$. The best colonies' diameter was produced in medium with $\mathrm{pH} 10$, while the medium with $\mathrm{pH} 12$ had a decrease in the size of colonies' diameter. Based on the chart of the colonies' diameter (Figure 5), bacterial isolates L2 could grow well in medium with $\mathrm{pH}$ 10. Therefore, the bacteria in isolate L2 may be predicted to belonged to alkaliphilic group.

The diameter measurements of isolate L2's clear-zone in media with different $\mathrm{pH}$ showed that the diameter of clear-zone in the medium with $\mathrm{pH}$ 7 was not different significantly from the others with $\mathrm{pH} 8, \mathrm{pH} 9$ and $\mathrm{pH} 12$. However, it was significantly different from to the others with $\mathrm{pH}$ 10 and 11. The clear zone's diameter in the medium with $\mathrm{pH} 8$ was not different significantly from the others in media with $\mathrm{pH} 9, \mathrm{pH} 10, \mathrm{pH} 11$ and $\mathrm{pH} 12$, but different significantly to the others in the medium with $\mathrm{pH} \mathrm{7.} \mathrm{The} \mathrm{best} \mathrm{clear} \mathrm{zone's}$ diameter was produced in the medium with $\mathrm{pH}$ 11, thereby the enzyme produced by bacteria isolates L2 may be predicted as an alkaline protease enzyme.

\section{Measurement of Proteolytic Index}

The measurement of proteolytic index aims to determine the ability of bacteria to have protease enzyme activity in a good quality (Syafie et al., 2013). This was characterized by the appearance of clear-zone around bacterial colonies. The proteolytic index of bacterial isolate L2 was not affected by treatment of different media (Table 1). This means that the different $\mathrm{pH}$ treatments applied to the media did not affect the proteolytic index of bacterial isolate L2.

\section{Protease Enzyme Characterization}

The different $\mathrm{pH}$ did not effect on the enzyme activity unit and the enzyme specific activity (Table 2). The highest enzyme activity unit and enzyme specific activity could be seen at $\mathrm{pH}$ 11. This showed that the optimum enzyme activity of isolate $\mathrm{L} 2$ was at $\mathrm{pH} 11$. The enzyme activity based on different temperature had no significant difference (Table 3). However, the

Table 1. Measurement Results of Colony's Diameter, Clear-zone's Diameter and Proteolytic Index of L2

\begin{tabular}{lcccccc}
\hline \multirow{2}{*}{\multicolumn{1}{c}{ Parameters }} & \multicolumn{6}{c}{$\mathrm{pH}$} \\
\cline { 2 - 7 } & 7 & 8 & 9 & 10 & 11 & 12 \\
\hline Colony's diameter & $2.56 \pm 0.67^{\mathrm{a}}$ & $2.66 \pm 0.40^{\mathrm{a}}$ & $2.57 \pm 0.38^{\mathrm{a}}$ & $3.48 \pm 0.26^{\mathrm{b}}$ & $3.38 \pm 0.52^{\mathrm{b}}$ & $2.68 \pm 0.35^{\mathrm{a}}$ \\
Clear-zone's diameter & $3.48 \pm 0.68^{\mathrm{a}}$ & $3.96 \pm 0.61^{\mathrm{ab}}$ & $3.71 \pm 0.45^{\mathrm{ab}}$ & $4.39 \pm 0.23^{\mathrm{b}}$ & $4.43 \pm 0.31^{\mathrm{b}}$ & $3.86 \pm 0.21^{\mathrm{ab}}$ \\
Proteolytic index $^{\mathrm{ns}}$ & $2.39 \pm 0.10$ & $2.45 \pm 0.10$ & $2.45 \pm 0.05$ & $2.27 \pm 0.09$ & $2.33 \pm 0.14$ & $2.45 \pm 0.15$ \\
\hline
\end{tabular}

Mean with different superscript in the same indicate significantly different $(\mathrm{P}<0.05)$; ns: non-significant $(\mathrm{P}>0.05)$.

Table 2. Test Results of Enzyme Unit Activity and Enzyme Specific Activity in Bacterial Isolate L2 Based on $\mathrm{pH}$ Treatments.

\begin{tabular}{lcccccc}
\hline \multirow{2}{*}{ Parameters } & \multicolumn{7}{c}{$\mathrm{pH}$} \\
\cline { 2 - 7 } & 7 & 8 & 9 & 10 & 11 & 12 \\
\hline $\begin{array}{l}\text { Enzyme unit } \\
\text { activity(U/mL) }\end{array}$ & $39.48 \pm 2.29$ & $39.11 \pm 1.27$ & $40.89 \pm 3.28$ & $42.69 \pm 2.26$ & $45.18 \pm 1.77$ & $37.69 \pm 1.27$ \\
$\begin{array}{l}\text { Enzime specific } \\
\text { activity (U/mg) }^{\text {ns }}\end{array}$ & $37.73 \pm 2.18$ & $37.39 \pm 1.21$ & $39.1 \pm 3.14$ & $40.81 \pm 2.17$ & $43.19 \pm 1.69$ & $36.88 \pm 2.42$ \\
\hline
\end{tabular}

Mean with different superscript in the same indicate significantly different $(\mathrm{P}<0.05)$; ns: non-significant $(\mathrm{P}>0.05)$. 
Table 3. Enzyme Activity Based on Temperature Treatments

\begin{tabular}{lccc}
\hline \multirow{2}{*}{\multicolumn{1}{c}{ Parameters }} & \multicolumn{3}{c}{ Temperature $\left({ }^{\circ} \mathrm{C}\right)$} \\
\cline { 2 - 4 } & 40 & 50 & 60 \\
\hline Enzyme unit activity $(\mathrm{U} / \mathrm{mL})^{\mathrm{ns}}$ & $54.02 \pm 1.89$ & $49.20 \pm 2.40$ & $50.00 \pm 2.52$ \\
Enzyme specific activity $(\mathrm{U} / \mathrm{mg})^{\mathrm{ns}}$ & $51.65 \pm 1.80$ & $47.05 \pm 2.29$ & $47.81 \pm 2.42$ \\
\hline
\end{tabular}

Mean with different superscript in the same indicate significantly different $(\mathrm{P}<0.05)$; ns: non-significant $(\mathrm{P}>0.05)$.

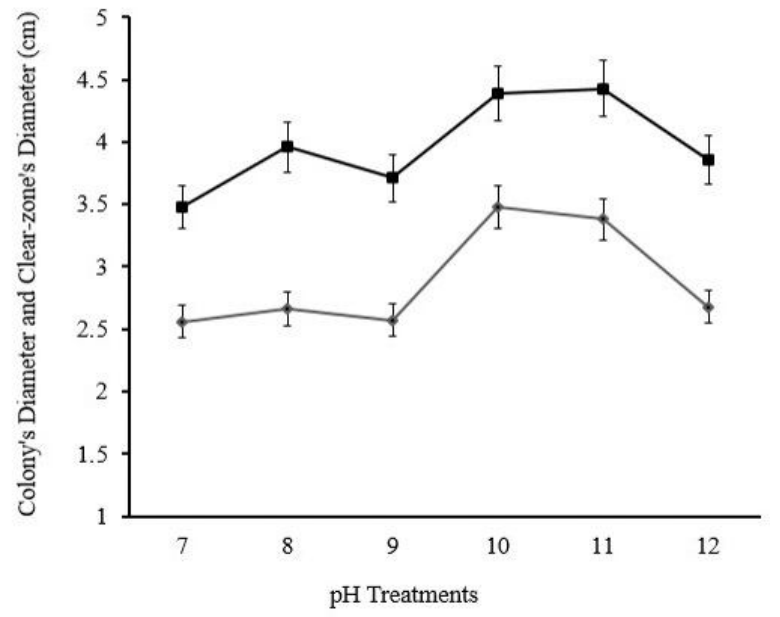

Figure 5. Colony's diameter and clear-zone's diameter of bacterial isolate L2 in agar medium with $\mathrm{pH}$ treatments. The symbols represent immobilized colony's diameter $(\diamond)$ and clearzone's diameter (ם).

enzyme activity may be optimum at $40^{\circ} \mathrm{C}$. This indicates that the enzyme of isolate L2 may work optimally at $40^{\circ} \mathrm{C}$.

\section{Enzyme Precipitation with 60\% Ammonium Sulfate}

The results of activity measurement showed that the crude enzyme unit which had been precipitated with $60 \%$ ammonium sulfate had higher activity, namely $75.8 \mathrm{U} / \mathrm{mL}$, when compared to the activity of crude enzyme unit without precipitation.

\section{DISCUSSION}

The bacterial isolate L2 may have the best proteolytic activity. The proteolytic activity of bacterial isolates were characterized by the presence of clear-zone surrounding the bacterial colonies. With the bacterial extracellular proteolytic enzymes, the casein will be hydrolyzed into peptides and amino acids that dissolved in the medium. The disappearance of casein particles in skim milk media was characterized by lysis zone (clear-zone) around bacterial colonies (Thanikaivelan et al., 2004; Pakpahan, 2009). Based on the identification of bacterial isolate L2, the bacteria may be the class of Bacillus. The characteristics of Bacillus bacteria are rod or bacillus-shaped, not moving or non-motile (Gupte, 1990)

The bacterial isolate L2 had a clear zone around the colony (Figure 3). The level of proteolytic enzyme activity was indicated by the wide clear zone. However, the activity level of proteolytic enzymes which remodel the protein in solid medium may not be identified and measured quantitatively. The hydrolysis activity is qualitatively an illustration of the ability of proteolytic bacterial isolates to remodel protein by comparing the size of the clear zone around the colony with the diameter of the colony (Widhyastuti et al., 2001). The results of protein polymer remodeling are shown by a clear zone which marks the reformation of the protein into peptides and amino acids compounds that are dissolved in the medium.

Protease enzymes may be divided into acidic, neutral and alkaline proteases based on their optimum $\mathrm{pH}$ (Nadeem et al., 2007). The $\mathrm{pH}$ range from 8 to 12 can be categorized as alkaline protease. Thus, the protease enzyme produced by isolate L2 was an alkaline since the enzyme activity showed a high level (Figure 6) and worked optimally at alkaline $\mathrm{pH}(\mathrm{pH} 11)$. The best protease enzyme activity could be achieved at $40^{\circ} \mathrm{C}$ (Figure 7). In general, any enzyme shows a maximum activity at certain temperature (Baehaki et al., 2011). The activity increases in line with the increasing temperature until the optimum temperature is reached. However, the high temperature will affect the substrate 


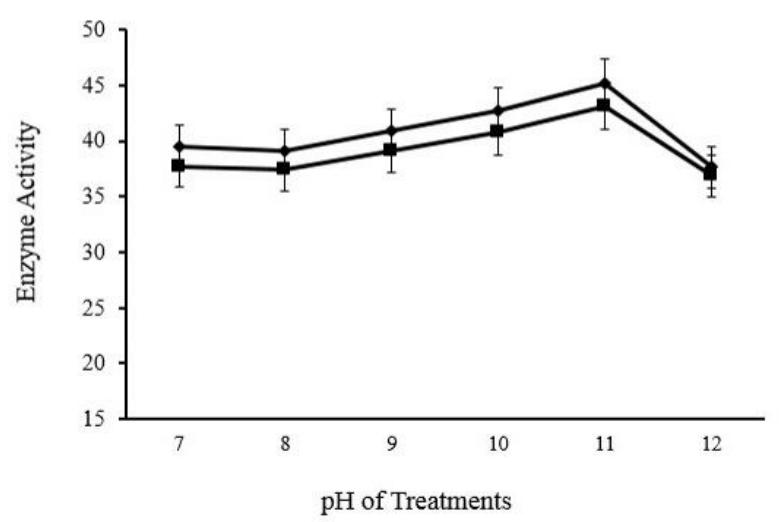

Figure 6. Enzyme unit activity and enzyme specific activity based on $\mathrm{pH}$ treatments. The symbols represent immobilized enzyme unit activity $(\mathrm{U} / \mathrm{mL})(\diamond)$ and enzyme specific activity $(\mathrm{U} / \mathrm{mg})(\mathbf{\square})$.

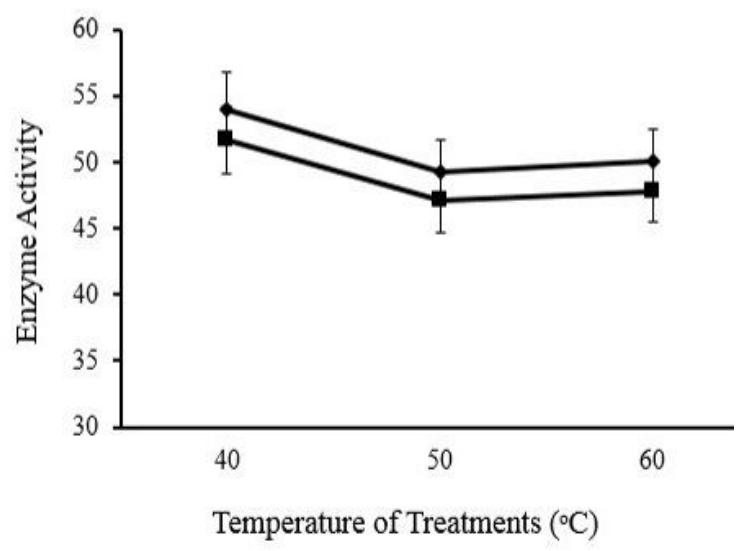

Figure 7. Enzyme unit activity and enzyme specific activity based on temperature treatments. The symbols represent immobilized enzyme unit activity $(\mathrm{U} / \mathrm{mL})(\diamond)$ and enzyme specific activity (U/mg) (ם).

conformational changes so that the active side of the substrate faces barriers to enter the enzyme active site and cause a decrease in enzyme activity.

Enzyme precipitation with ammonium sulfate is one of the ways to purify the proteins through a salt deposition process (Fatoni et al., 2008). The fractionation was conducted with ammonium sulfate saturation of $15 \%, 30 \%, 45 \%$ and $60 \%$. The protease purification of
Staphyllococcus sp showed that the fraction with $60 \%$ degree of saturation had the highest activity. Therefore, the concentration of ammonium sulfate used in the study was $60 \%$. The crude enzyme unit which had been precipitated with $60 \%$ ammonium sulfate had the higher activity level, namely $75.8 \mathrm{U} / \mathrm{mL}$, when compared to the activity of the crude enzyme unit without precipitation. Te protease enzyme activity of Aspergillus niger precipitated using ammonium sulfate has the enzyme unit activity of $69.3 \mathrm{U} / \mathrm{mL}$ and the enzyme specific activity of $27.07 \mathrm{U} / \mathrm{mg}$ (Devi et al., 2008).

\section{CONCLUSION}

The morphology of the colony from isolat L2 was circle, white, flat ledges and convex elevation, the basal cell morphology was red, Gram-negative, non-motile, and catalase positive. The biggest diameter of bacterial colony and the clear zone was obtained in the medium with $\mathrm{pH}$ of 10 and 11 . The highest enzymatic activity was at pH 11 with the enzymatic activity unit $45.18 \pm 1.77$ $\mathrm{U} / \mathrm{mL}$ and the specific activity $43.19 \pm 1.69 \mathrm{U} / \mathrm{mg}$, while at temperature $40^{\circ} \mathrm{C}$, the enzymatic activity unit is $54.02 \pm 1.89 \mathrm{U} / \mathrm{mL}$ and the specific activity is $51.65 \pm 1.8 \mathrm{U} / \mathrm{mg}$.

\section{REFERENCES}

Ahmed, S.A., R.A. Al-domany, N.M.A. El-Shyeb, H.H. Radwan and S.A. Saleh. 2008. Optimization, immobilization of extracellular alkaline protease and characterization of its enzymatic properties. Res. J. Agr. Biol. Sci. 4: 434-446.

Agrawal, D., P. Patidar, T. Banerjee and S. Patil. 2004. Production of alkaline protease by Penicillum sp. under SSF conditions and its application to soy protein hydrolysis. Process Biochemistry, 39: 977-981.

Alexander, K.T.W., D.R. Corning, N.J. Cory, V.J. Donohue and R.L. Sykes. 1991. Environmental and safety issues-clean technology and environmental auditing. J. Soc. Leather Technol. Chem. 76: 17-23.

Baehaki, A., Rinto dan A. Budiman. 2011. Isolasi dan karakterisasi protease dari bakteri tanah rawa Indralaya, Sumatera Selatan [Isolation and characterization of proteases from Indralaya soil swamp bacteria, Soulth Sumatera]. J. Teknol. dan Industri Pangan. 22: $10-16$. 
Devi, K.M., A.R. Banu, G.R. Gnanaprabhal, B.V. Pradeep and M. Palaniswamy. 2008. Purification, characterization of alkaline protease enzyme from native isolate Aspergillus niger and its compatibility with commercial detergents. Indian J. Sci. Technol. 1: 1-6.

Fatoni, A., Zusfahair dan P. Lestari. 2008. Isolasi dan karakterisasi protease ekstraseluler dari bakteri dalam limbah cair tahu. Jurnal Natur Indonesia, 10: 83-88.

Fuad, A.M., R. Rahmawati dan N.R. Mubarik. 2004. Produksi dan karakterisasi parsial protease alkali termostabil Bacillus thermoglucosidasius AF-01. Jurnal Mirobiologi Indonesia. 9:29-35.

Gupte, S. 1990. Mikrobiologi Dasar. Binarupa Aksara. Jakarta.

Kumari, S. 2014. Extracellular protease enzyme production using Micrococcus luteus-4, Staphylococcus hyicus, Micrococcus luteus1, Pasteurella pneumotrop and Micrococcus $s p$. isolated from water reservoirs. Int. J. Curr. Microbiol. App. Sci., 3: 772-784.

Miyamoto, K., H. Tsujibo, E. Nukui, H. Itoh, Y. Kaidzu and Y. Inamori. 2002. Isolation and characterization of the genes encoding two metalloproteases (MprI and MprII) from a marine bacterium, Alteromonas sp. strain O7. Biosci. Biotecnol. Biochem., 66: 416- 21.

Nadeem, M. J.I. Qazi, S. Baig and Q. Syed. 2007. Studies on commercially important alkaline protease from Bacillus lichniformis $\mathrm{N}-2$ isolated from decaying organic soil. Turk. J. Biochem. 32: 171-177.

Noble, J.E. and M.J.A. Bailey. 2009. Quantitation of Protein. Methods Enzymol. 463: 73-95.

Pakpahan, R. 2009. Isolasi Bakteri dan Uji Aktivitas Protease Termofilik dari Sumber Air Panas Sipoholon Tapanuli Utara Sumatera Utara. MP Tesis. Sekolah Pascasarjana Universitas Sumatera Utara. Medan.

Rahayu, K. 1991. Isolasi dan Pengujian Aktivitas Enzim. PAU Pangan dan Gizi. Universitas Gadjah Mada Press. Yogyakarta.

Rajasa, H. 2003. Opening speech: $3^{\text {nd }}$ Conference on Industrial Enzyme and Biotechnology. Technology and Business Opportunity for Industrial Enzyme in Harmony with Environment. Agency for the Assessment and Application of Technology (BPPT). Jakarta, October 6-7, 2003.

Rao, M.B., A.M. Tanksale, M.S. Ghatge and V.V.
Deshpande. 1998. Molecular and biotechnological aspect of microbial proteases. Microbiol. Mol. Biol. Rev. 62: 597-635.

Schmidt, J., M. Müsken, T. Becker, Z. Magnowska, D. Bertinetti, S. Möller, B. Zimmermann, F.W. Herberg, L. Jänsch and S. Häussler. 2011. The Pseudomonas aeruginosa chemotaxis methyltrasferase CheR1 impacts on bacterial surface sampling. PLoS ONE, 6: e18184. doi:10.1371/journal.pone.0018184.

Suhartono, M.T., 2000. Eksplorasi protease bakteri asal Indonesia untuk aplikasi industri dan riset bioteknologi. Prosiding Seminar Nasional Industri Enzim dan Bioteknologi II, pp. 125-133.

Syafie, Y., S. Triatmojo dan A. Pertiwiningrum. 2013. Penggunaan protease Aspergillus sp. dan Rhizopus sp. dengan konsentrasi yang berbeda dalam tahapan unhairing terhadap kualitas fisik dan limbah cair pada penyamakan kulit domba [The utilization of Aspergillus sp. and Rhizopus sp. protease at different concentration in unhairing phase of tanning on physical quality of sheep leather and liquid waste]. Buletin Peternakan, 37: 198-206.

Tejaswini, A.V.N., S. Ranjan and V. Sridevi. 2014. Extraction, partial purification and characterization of protease enzyme from isolated bacterium bacillus subtilis and optimization of few culture conditions. International Journal of Advanced Research, 2: 456-462.

Thanikaivelan, P., J.R. Rao, B.U. Nair, and T. Ramasami. 2004. Progress and recent trends in biotechnological methods for leather processing. Trends in Biotechnology, 22: 181-188.

Thomas, D.B. 1989. A Textbook of Industrial Microbiology. Second Edition. Sinauer Associates. Sunderland. USA.

Vázquez, S.C., E. Hernández and W.P.M. Cormack. 2008. Extracellular proteases from the antarctic marine Pseudoalteromonas $s p$. P96-47 strain. Rev. Argent. Microbiol., 40: 63-71.

Ward, O.P., M.B. Rao and A. Kulkarni. 2009. Proteases, Production. Applied Microbiology: Industrial, PP. 495-511.

Widhyastuti, N. dan R.M. Dewi. 2001. Isolasi bakteri proteolitik dan optimasi produksi protease. Laporan Teknik Proyek 
Inventarisasi dan Karakterisasi Sumberdaya Hayati. Pusat Penelitian Biologi - LIPI Bogor.
Widodo, S. 1984. Pengelolaan Limbah Industri Penyamakan Kulit Bagian I. Akademi Teknologi Kulit, Yogyakarta. 